\title{
Correction to: Sustainable transitions towards a resilient and decentralised future: Japan's Circulating and Ecological Sphere (CES)
}

\author{
Fernando Ortiz-Moya ${ }^{1}\left[\right.$ Patsuka Kataoka ${ }^{1} \cdot$ Osamu Saito $^{1,2} \cdot$ Bijon Kumer Mitra $^{1} \cdot$ Kazuhiko Takeuchi $^{1,2}$
}

Published online: 3 May 2021

(c) The Author(s) 2021, corrected publication 2021

\section{Correction to: Sustainability Science https://doi.org/10.1007/s11625-021-00941-y}

The article Sustainable transitions towards a resilient and decentralised future: Japan's Circulating and Ecological Sphere (CES), written by Fernando Ortiz Moya, Yatsuka Kataoka, Osamu Saito, Bijon Kumer Mitra and Kazuhiko Takeuchi, was originally published electronically on the publisher's internet portal on March 31, 2021 without open access. With the author(s)' decision to opt for Open Choice the copyright of the article changed on April 15, 2021 to (C) The Author(s) 2021 and the article is forthwith distributed under a Creative Commons Attribution 4.0 International License (https://creativecommons.org/licenses/by/4.0/), which permits use, sharing, adaptation, distribution and reproduction in any medium or format, as long as you give appropriate credit to the original author(s) and the source, provide a link to the Creative Commons license, and indicate if changes were made.

The original article has been updated.
Funding Open access publication was funded by the Institute for Global Environmental Strategies (IGES) and the Environment Research and Technology Development Fund (S-15, JPMEERF16S11500), Ministry of the Environment, Japan.

Open Access This article is licensed under a Creative Commons Attribution 4.0 International License, which permits use, sharing, adaptation, distribution and reproduction in any medium or format, as long as you give appropriate credit to the original author(s) and the source, provide a link to the Creative Commons licence, and indicate if changes were made. The images or other third party material in this article are included in the article's Creative Commons licence, unless indicated otherwise in a credit line to the material. If material is not included in the article's Creative Commons licence and your intended use is not permitted by statutory regulation or exceeds the permitted use, you will need to obtain permission directly from the copyright holder. To view a copy of this licence, visit http://creativecommons.org/licenses/by/4.0/.

Publisher's Note Springer Nature remains neutral with regard to jurisdictional claims in published maps and institutional affiliations.

The original article can be found online at https://doi.org/10.1007/ s11625-021-00941-y.

Fernando Ortiz-Moya

ortiz-moya@iges.or.jp

1 Institute for Global Environmental Strategies, 2108-11, Kamiyamaguchi, Hayama, Kanagawa 240-0115, Japan

2 Institute for Future Initiatives, The University of Tokyo, 7-3-1 Hongo, Bunkyo-ku, Tokyo 113-0033, Japan 